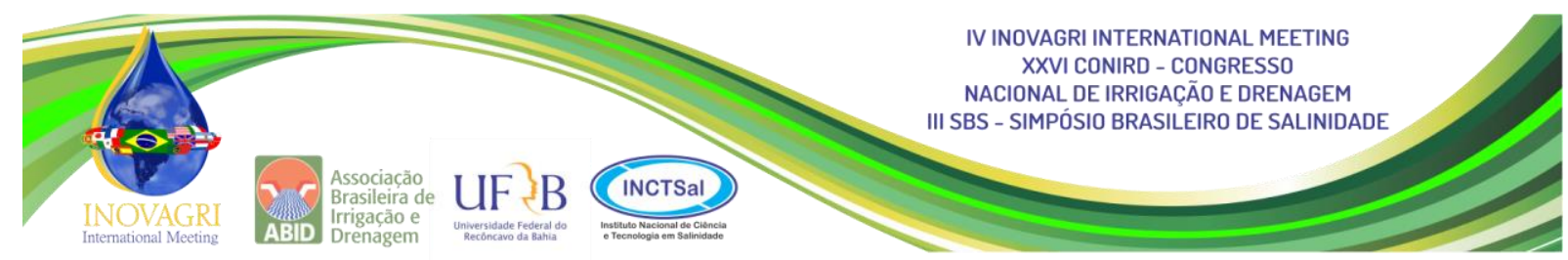

\title{
COMPARISON OF WATER CONSUMPTION ESTIMATE FOR Urochloa brizantha cv. MARANDU WITH FDR PROBE AND WEIGHTING LYSIMETER
}

\author{
D. P. Souza ${ }^{1}$, A. C. Sanches ${ }^{2}$, R. G. Maffei ${ }^{3}$, F. L. F. Jesus ${ }^{4}$, F. C. Mendonça ${ }^{5}$, \\ J. R. M. Pezzopane ${ }^{6}$
}

\begin{abstract}
Capacitive probes are devices with high investment costs, but they have the advantage of mobility and practical use compared with lysimeters. Therefore, studies are needed to verify the use of this technique in the determination of water consumption by forage plants. The objective of this work was to evaluate the use of a capacitive probe to estimate the water consumption in two cropping systems compared to the data obtained by the weighing lysimeter. They were: single (Marandu palisadegrass) and consortium (Marandu palisadegrass+ black oats + ryegrass). The study was carried out in an experimental area of ESALQ/USP. Data from six cycles of Marandu palisadegrass development were used, four in exclusive cultivation and two in consortium cultivation. Soil moisture was evaluated by the Diviner ${ }^{\circledR}$ capacitive probe and used to calculate the soil water balance. The coefficient of culture data (Kc) estimated by the capacitive probes were correlated with those determined in the weighing lysimeters, correlations were significant $(\mathrm{p}<0,05)$ and linear equations. The estimates made with the probe differed from those made with lysimeters overestimating $78 \%$ of the studied cases, Kc values of the probes in relation to lysimeters.
\end{abstract}

KEY WORDS: Capacitive probe; Coefficient of culture; Crop evapotranspiration

\section{COMPARAÇÃO DA ESTIMATIVA DE CONSUMO DE ÁGUA PARA Urochloa brizantha cv. MARANDU COM SONDA FDR E LISÍMETRO DE PESAGEM}

RESUMO: As sondas capacitivas são aparelhos com alto custo de investimento, porém possuem a vantagem da mobilidade e praticidade em relação aos lisímetros. O objetivo desse trabalho foi avaliar o uso de uma sonda capacitiva para estimativa do consumo de água em

\footnotetext{
1 Engenheira Agrônoma, Doutoranda em Engenharia de Sistemas Agrícolas (ESALQ/USP), Av. Pádua dias, 11 (LEB), CEP:13418-900, Piracicaba/SP, Fone (19) 34478578 ramal 29, e-mail: dpdsouza@usp.br.

${ }^{2}$ Doutorando em Engenharia de Sistemas Agrícolas, ESALQ/USP, Piracicaba/SP, arthur_caniato@usp.br.

${ }^{3}$ Acadêmico de Engenharia Agronômica, ESALQ/USP, Piracicaba,SP, rodolfo.guertas.maffei@usp.br.

${ }^{4}$ Doutoranda em Engenharia de Sistemas Agrícolas, ESALQ/USP, Piracicaba/SP, fernandalamede@usp.br.

${ }^{5}$ Professor Doutor, Depto de Engenharia de biossistemas, ESALQ/USP, fernando.mendonca@usp.br

${ }^{6}$ Pesquisador Doutor, Empraba - Centro de Pesquisa de Pecuária do Sudeste, São Carlos/SP, jose.pezzopane@embrapa.br.
} 
relação a medidas de lisímetros de pesagem, em dois sistemas de cultivo. Os quais foram: solteiro (Marandu) e consorciado (Marandu + aveia-preta + azevém). O trabalho foi realizado em área experimental na ESALQ/USP. Foram utilizados dados de seis ciclos de desenvolvimento do capim Marandu, sendo quatro em cultivo exclusivo e dois em cultivo. A umidade de solo foi avaliada pela sonda capacitiva Diviner@ e utilizados para cálculo de balanço hídrico no solo. Os dados de coeficiente de cultura $(\mathrm{Kc})$ estimados pelas sondas capacitivas foram correlacionados com os determinados nos lisímetros de pesagem, as correlações foram significativas $(\mathrm{p}<0,05)$ e lineares na metade das comparações. As estimativas feitas com a sonda diferiram daquelas feitas com os lisímetros, superestimando $78 \%$ dos casos estudado, valores de Kc das sondas em relação aos lisímetros.

PALAVRAS-CHAVES: Sonda capacitiva; Coeficiente de cultura; evapotranspiração de cultura.

\section{INTRODUCTION}

Measuring or estimating the water consumption of plants is the basic point for irrigation management, which can be calculated by various methods, direct and indirect (PRIMO et al., 2015). The gravimetric analysis is an example of a direct method, and the indirect ones are: neutron dispersion, capacitance, time domain reflectometry (TDR), frequency domain reflectometry (FDR) and measurement of the soil-water potential (ANDRADE JUNIOR; SILVA; DANIEL, 2007; ALLEN et al., 2011).

The most accessible method to all users is gravimetric analysis, because is accurate and reliable. However, it presents some limitations, such as the time to obtain the results, which can take up to 3 days (ALLEN et al., 2011).

The great advantage of indirect methods is because they estimate the soil moisture from the physical properties, which allows many readings in the same place without the destruction of the soil with samples collection (SOUZA et al., 2016). The FDR sensor used is introduced into tubes installed vertically in the soil profile without moving the soil profile off the tube (EVETT et al., 2012). These methods are alternatives to the weighing lysimeters, because present high cost of implantation and corrective repair (HOFFMANN et al., 2016).

The basic principle of operation is given by means of a high frequency electric field formed by the sensor. This electric field is altered according to the amount of water molecules in the site (FRANCISCO et al., 2014). The Diviner $2000^{\circledR}$ probe is an example of a FDR sensor. 
However, this method has some characteristics that can lead to estimation errors. Among them, the spatial and vertical variability of soil density caused for growth of the root zone and differences in soil wetting due to the variation of rainfall or irrigation, which may lead to overestimation of water addition (EVETT; TOLK; HOWELL, 2006). In addition, other problems can be found such as the constant trampling around the access tube, modified the infiltration of water in the soil, obtaining an incorrect estimates of evapotranspiration (ALLEN et al., 2011).

There are several works with calibration of the FDR probes for use in different types of soil for the application of technique on water management (ANDRADE JUNIOR; SILVA; DANIEL, 2007; SILVA et al., 2007; LIMA FILHO; COELHO FILHO; COELHO, 2013; SOUZA et al., 2013; FRANCISCO et al., 2014; PRIMO et al., 2015).

The comparison of the use of the FDR, by means of the soil water balance, with other methods aims to identify the potential use of the capacitive probe as a method of determining the water consumption by the plants. Then, the objective of this study was to evaluate the performance of a FDR probe to estimate the water consumption of Urochloa brizantha cv. Marandu in two cultivation systems, single and intercropped with oat and ryegrass.

\section{MATERIAL AND METHODS}

The experiment was carried out at the Escola Superior de Agricultura "Luiz de Queiroz" (ESALQ/USP) Piracicaba/SP city. Two plots with a unit size of $144 \mathrm{~m}^{2}$ were used, inside each were installed three access tubes for data collection with the capacitive probe. At the center of each plot was a weighing lysimeter, which was used to compare the results (Figure 1).

The soil of the experimental area is classified Eutrophic Red Nitosol (SANTOS et al., 2013). The soil presents average levels of $32.5 \%$ of sand, $18.95 \%$ of silt and $48.55 \%$ of clay (depth of $0.4 \mathrm{~m}$ - higher root concentration).

The cutting cycles were compared, four cutting cycles of Urochloa brizantha cv. Marandu single during the interval from $7^{\text {th }}$ April to $4^{\text {th }}$ May, $24^{\text {th }}$ July to $11^{\text {th }}$ October at 2016, and two cycles of cut in the second plot, composed by the same crop, but was carried out the overestimation with black oats and Italian ryegrass with utilization of data from $5^{\text {th }}$ August to $7^{\text {th }}$ October, 2016.

The experimental area was irrigated by the conventional sprinkler, according to the crop requirements, determined by the consumption registered in the weighing lysimeter. In total, 221 and $202 \mathrm{~mm}$ of water were irrigated in areas A1 and A2, respectively, as the dates of the cycles 
were close to the cumulative sum of rainfall in both areas were equal, with a total of $93.2 \mathrm{~mm}$ (Figure 2 ).

The capacitive probe used was model Diviner ${ }^{\circledR}$ (Sentek), with a probe stem of $1.6 \mathrm{~m}$ in length. In this study, the access tubes (AT), made of PVC and with a specific diameter for the sensor, were installed according to the manufacturer's recommendations. Each installed tube had a length of $0.9 \mathrm{~m}$, with a reading capacity of up to $0.7 \mathrm{~m}$. The depth of the weighing lysimeter was $0.6 \mathrm{~m}$, with an automated drainage system as presented by Sanches et al., 2016.

Before calibration, the capacitive probe was normalized and calibrated as recommended by the manufacturer. Since the water frequency normalization (Fw) of $126686 \mathrm{MHz}$ and the air frequency (Fa) of $183186 \mathrm{MHz}$ (SENTEK, 2011).

When inserted into the soil, the probe will emit a frequency of soil oscillation (Fs), which is converted to the scaled frequency (SF) through of the programming. The calibration of the probe was done for the soil of the experimental area according to the manufacturer's recommendation, in five moments with different soil moisture (10 to $50 \%$ of based on volume). The SF conversion to volumetric moisture $(\theta)$ is found in Equation 1.

$$
\mathbf{S F}=0,2799 \boldsymbol{\theta}^{3,07882}
$$

Where,

$\boldsymbol{\theta}$ - volumetric moisture (\%)

SF - scaled frequency, dimensionless.

The probe readings were performed daily to verify the optimal interval between readings. With the observation of the results, was adopted the variations of soil moisture in intervals of four days.

The crop evapotranspiration (ETc) was calculated by means of the soil-water balance, represented in Equation 2, adapted from the citation of Evett et al. (2012).

$$
\mathbf{E T c}=-\Delta \mathbf{S}+\mathbf{P}+\mathbf{I}-\mathbf{R}+\mathbf{F}
$$

Em que,

ETc - crop evapotranspiration, $\mathrm{mm} \mathrm{dia}^{-1}$

$\Delta \mathbf{S}$ - change in soil water storage over, $\mathrm{mm} \mathrm{dia}^{-1}$

$\mathbf{P}$ - rainfall, $\mathrm{mm} \mathrm{dia}^{-1}$

I - irrigation, $\mathrm{mm} \mathrm{dia}^{-1}$

$\mathbf{R}$ - runoff, $\mathrm{mm} \mathrm{dia}^{-1}$

F - deep soil water flux, mm dia ${ }^{-1}$ 
The runoff was disregarded, because the plot were small and low declivity, with correct applications the water on proceedings irrigations.

The flow of water in the soil occurs when at a certain depth there is an increase of moisture without any new entries (rainfall or irrigation), given by lateral water flow or capillary ascension, when this flow occurs in depth is considered drainage and this has a negative value in the equation (EVETT et al., 2012).

The drainage was computed when the volume of moisture content Diviner recorded in the depth from 0.6 to $0.7 \mathrm{~m}$ increased with respect to the moisture of the previous layer (from 0.5 to $0.6 \mathrm{~m})$.

The crop evapotranspiration (ETc) were measured by the weighing lysimeters for comparison with the data estimated by Diviner. To calculate the reference evapotranspiration (ETo) were used ESALQ Meteorological Station data, with the Penman-Monteith model, the recommendation by FAO-56 (ALLEN et al., 1998, 2006). With the accumulated values of ETo and ETc per cycle, Kc values were proposed for the different phases of the single and oversized Marandu palisadegrass cycles.

The data were submitted to comparative analysis by Student's t-test using the ASSISTAT 7.7 software (SILVA; AZEVEDO, 2002) and descriptive analysis.

\section{RESULTS AND DISCUSSION}

Simple correlation tests were performed between the Kc values determined by the lysimeter (L) and those determined with the FDR probe in each Diviner access tube $\left(\mathrm{AT}_{1}, \mathrm{AT}_{2}\right.$ and $\mathrm{AT}_{3}$ in $\mathrm{P}_{1} ; \mathrm{AT}_{4}, \mathrm{AT}_{5}$ and $\mathrm{AT}_{6}$ in $\mathrm{P}_{2}$ ), comparing the results by Student's t-test, those presented in Table 1.

Some values determined in both methods had linear and significant behavior. In the plot $1(\mathrm{P} 1)$, the correlation of the Kc obtained in the lysimeter and in the Diviner access tubes (AT1, $\mathrm{AT}_{2}$ and $\left.\mathrm{AT}_{3}\right)$ was significant in cycles $\mathrm{C}_{1}(\alpha=1 \%)$ and $\mathrm{C}_{3}\left(\mathrm{LP}_{1 \mathrm{AT}}\right)$ with $\alpha=1 \%$. For the cycle 2, the comparison between lysimeters and probe showed no significant correlation. Regardless of the cycle, the interactions between the ATs were significant ( $\alpha=1 \%$ and $5 \%$ ), showing that the behavior between them is similar.

The correlation made in $\mathrm{P}_{2}$ showed that for the 2 and 3 cycles $(\mathrm{C} 2, \mathrm{C} 3)$ there was no significant correlation between the values determined in the AT points and the lysimeter. Only in cycle $1(\mathrm{C} 1)$ there was a significant difference of $1 \%$ between the lysimeter and $\mathrm{AT}_{4}, \mathrm{AT}_{6}$, and in cycle 3 , there was a significance of $5 \%$ for AT6. 
Similar to in $\mathrm{P}_{1}$, the AT measurements showed a significant correlation with each other, except in cycle 1 ( $\mathrm{AT}_{4} \times \mathrm{AT}_{6}$ ) cycle 3 ( $\mathrm{AT}_{2} \times \mathrm{AT}_{3}$ and $\mathrm{AT}_{5} \times \mathrm{AT}_{6}$ ), it's showed no significant correlation with the others.

This fact may have occurred due to not soil total accommodation around the access tubes, since the collection of data from cycle 1 was installed in the previous month, leading to the presentation of these faults. Due to the presented facts, it can be affirmed that the use of capacitive probes to estimate Kc needs to be evaluated in each situation, and that the installation of ATs must be performed very carefully.

Considering the interactions previously presented, the estimates of Kc obtained by the probes were compared with those observed in the lysimeters with analysis of mean error (ME), mean absolute error (MAE), root mean square error (RMSE) and Willmontt's concordance index, shown in Table 2.

It was observed that the determination of water consumption by the FDR probe was higher than the determination by weighing lysimeter, with better values for cycle 1 (plot 1 ), where $d=0,5946$, justifying the significant correlation between the previously presented variables. Observing the values of ETc observed in the lysimeters and estimated by the FDR probe, it is also noticed that the accumulated values are higher in all cycles studied.

From the data collected, the values of the crop coefficient were determined in initial ( $\left.K \mathrm{c}_{\text {initial }}\right)$, middles $\left(\mathrm{Kc}_{\text {middle }}\right)$ and final $\left(\mathrm{Kc}_{\text {final }}\right)$ cycles for the two methods (Table 2$)$. There was a large variation in the results obtained with the probe in relation to lysimeters. The most part of determination (72\%) per capacitive probe were overestimated in relation to the lysimeters and in only 5 points were underestimated.

When comparing the determination of evapotranspiration with the use of lysimeter and the ratio of Bowen (Thermocouple and Resistance Temperature Detector), authors verified the underestimation of Bowen's ratio (HENAREJOS; MARTÍNEZ; RUIZ, 2000). Another study compared the use of capacitive probes in relation to the neutron probe, verified that the capacitive probe is more sensitive to the change of moisture when the soil volume between drip point and sensor evaluated is higher (MOUNZER et al., 2007). Considering the sprinkler irrigation, where the water drops fall more dispersed in the area, the data variability is bigger.

\section{CONCLUSION}


In the first analysis, the capacitive probe overestimated the evapotranspiration in relation to the lysimeters of weighing, a larger volume of data is necessary to verify the sensitivity of the humidity change and the probe registration.

\section{ACKNOWLEDGMENTS}

The Fundação de Amparo à Pesquisa do Estado de São Paulo (FAPESP) on regular research project $n^{\circ} 2012 / 23002-6$.

\section{REFERENCES}

ALLEN, R. G.; PEREIRA, L. S.; HOWELL, T. A.; JENSEN, M. E. Evapotranspiration information reporting: I. Factors governing measurement accuracy. Agricultural Water Management, v. 98, n. 6, p. 899-920, 2011.

ALLEN, R. G.; PEREIRA, L. S.; RAES, D.; SMITH, M. Crop evapotranspiration: Guidelines for computing crop requirements. Irrigation and Drainage Paper No. 56, FAO, n. 56, p. 300, 1998. Disponível em: <http://www.kimberly.uidaho.edu/water/fao56/fao56.pdf>.

ALLEN, R. G.; PRUITT, W. O.; WRIGHT, J. L.; HOWELL, T. A.; VENTURA, F.; SNYDER, R.; ITENFISU, D.; STEDUTO, P.; BERENGENA, J.; YRISARRY, J. B.; SMITH, M.; PEREIRA, L. S.; RAES, D.; PERRIER, A.; ALVES, I.; WALTER, I.; ELLIOTT, R. A recommendation on standardized surface resistance for hourly calculation of reference ETo by the FAO56 Penman-Monteith method. Agricultural Water Management, v. 81, n. 1-2, p. 1$22,2006$.

ANDRADE JUNIOR, A. S. de; SILVA, C. R.; DANIEL, R. Calibração de um sensor capacitivo de umidade em Latossolo Amarelo na microrregião do Litoral Piauiense. Revista Brasileira de Ciencias Agrarias, v. 2, n. 4, p. 303-307, 2007.

EVETT, S. R.; SCHWARTZ, R. C.; CASANOVA, J. J.; HENG, L. K. Soil water sensing for water balance, ET and WUE. Agricultural Water Management, v. 104, p. 1-9, 2012. Disponível em: <http://dx.doi.org/10.1016/j.agwat.2011.12.002〉.

EVETT, S. R.; TOLK, J. a.; HOWELL, T. a. Soil Profile Water Content Determination. Vadose Zone Journal, v. 5, n. 3, p. 894, 2006.

FRANCISCO, J. P.; JOSÉ, J. V.; FERNANDES, R. D. M.; DIOTTO, A. V.; MARQUES, P. 
A. A.; FOLEGATTI, M. V. Acurácia e Calibração de Sonda de Capacitância em Um Nitossolo Vermelho Distrófico e Em Um Latossolo Vermelho Amarelo. In: II Inovagri International Meeting - 2014, April, Fortaleza. Anais... Fortaleza: 2014. Disponível em: $<$ http://www.bibliotekevirtual.org/index.php/2013-02-07-03-02-35/simposios/221-ii-inovagri2014/1633-ii-inovagri-2014-a258.html>.

HENAREJOS, D. E.; MARTÍNEZ, J. M. M.; RUIZ, A. Estudio comparativo del empleo de termopares y RTD en la estimación de la evapotranspiración mediante balance de energía. ACTAS DE HORTICULTURA, n. 60, p. 719-722, 2000.

HOFFMANN, M.; SCHWARTENGRÄBER, R.; WESSOLEK, G.; PETERS, A. Comparison of simple rain gauge measurements with precision lysimeter data. Atmospheric Research, v. 174-175, p. 120-123, 2016.

LIMA FILHO, A. F.; COELHO FILHO, M. A.; COELHO, E. F. Comunicação Científica Calibração de uma sonda FDR para determinação do conteúdo de água de um Latossolo Amarelo Material e Métodos. Magistra, v. 25, n. 3/4, p. 285-292, 2013.

MOUNZER, O.; RUIZ-SÁNCHEZ, M. C.; ABRISQUETA, I.; TAPIA, L. M.; VERA, J.; ABRISQUETA, J. M. Comparación de las medidas de humedad del suelo con diferentes sensores con fines de programación del riego localizado en frutales. VIII Jornadas de Investigación en la Zona no Saturada del Suelo. Estudios de la Zona No Saturada del Suelo, v. 8, p. 281-283, 2007.

PRIMO, J. T. de A.; DA SILVA, T. G. F.; SIQUEIRA E SILVA, S. M.; DE MOURA, M. S. B.; DE SOUZA, L. S. B. Calibração de sondas capacitivas, funções físico-hídricas e variação do armazenamento de água em um argissolo cultivado com palma forrageira. Revista Ceres, v. 62 , n. 1 , p. 20-29, 2015.

SANCHES, A. C.; DÉBORA PANTOJO DE SOUZA, F. C. M.; MAFFEI, R. G.; ANTONIA, B. DELLA. LISÍMETROS DE PESAGEM COM DRENAGEM AUTOMATIZADA: CONSTRUÇÃO E CALIBRAÇÃO -. In: XLV Congresso Brasileiro de Engenharia Agrícola, Florianópolis - SC. Anais... Florianópolis - SC: 2016.

SANTOS, H. G. dos; JACOMINE, P. K. T.; ANJOS, L. H. C. dos; OLIVEIRA, V. Á. D.; LUMBRERAS, J. F.; COELHO, M. R.; ALMEIDA, J. A. de.; CUNHA, T. J. F.; OLIVEIRA, J. B. de. Sistema brasileiro de classificação de solos. 3. ed. Brasília-DF: Embrapa, 2013.

SENTEK. Calibration manual: for sentek soil moisture. [s.l: s.n.] 
SILVA, C. R. da; ANDRADE JÚNIOR, A. S. de; ALVES JÚNIOR, J.; SOUZA, A. B. de; MELO, F. de B.; COELHO FILHO, M. A. Calibration of a capacitance probe in a Paleudult. Scientia Agricola, v. 64, n. 6, p. 636-640, 2007.

SILVA, F. de A. S.; AZEVEDO, C. A. V. de. Versão do programa computacional Assistat para o sistema operacional Windows. Revista Brasileira de Produtos Agroindustriais, p. 71-78, 2002.

SOUZA, D. P. de; SANCHES, A. C.; MENDONÇA, F. C.; CARNEVSKIS, E. L.; SARETTA, E. Evapotranspiração do capim Marandu determinada por lisimetro de pesagem: fase inicial. In: XLV Congresso Brasileiro de Engenharia Agrícola, Florianopolis. Anais... Florianopolis: 2016.

SOUZA, C. F.; CÉLIA, R.; PIRES, M.; MIRANDA, B. D. E.; CLAUDIO, E. A.; VARALLO, T. Calibração de sonda FDS e TDR para estimativa da umidade em dois tipos de solo. Irriga, v. 18 , n. 4, p. 597-606, 2013.

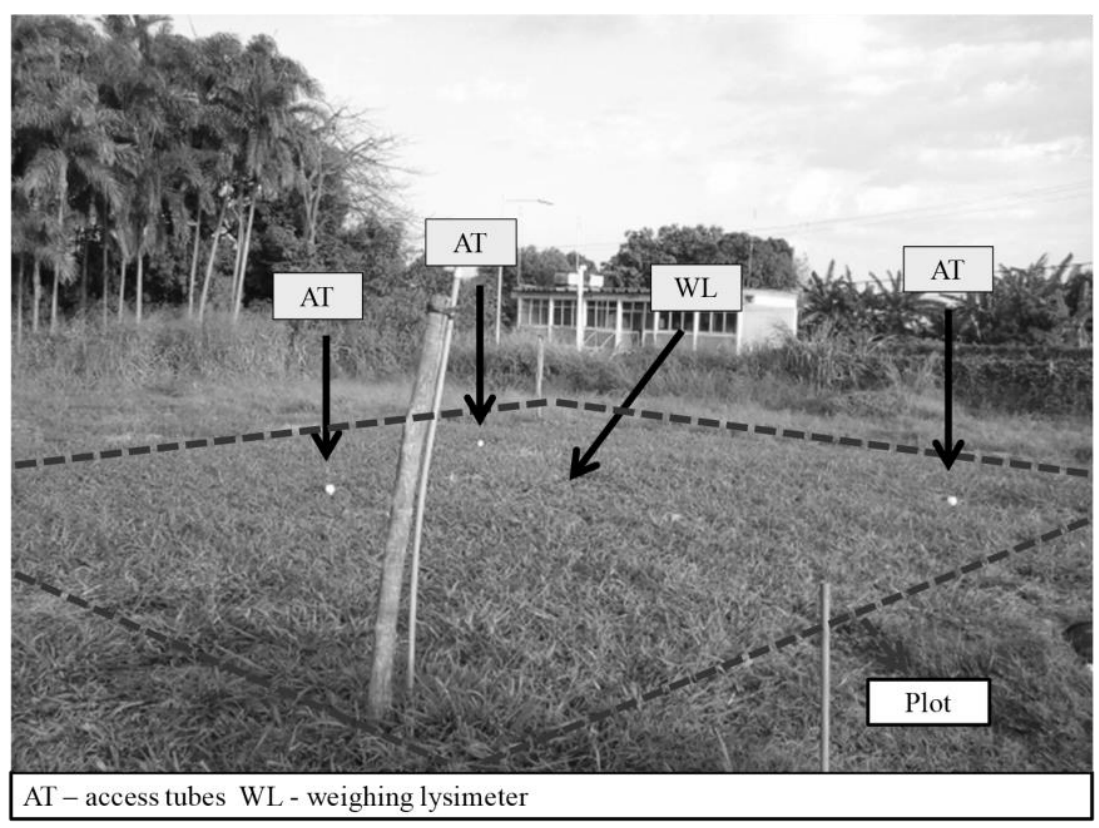

Figure 11. One experimental Plot: Access tubes (AT) and weighing lysimeter (WT). 


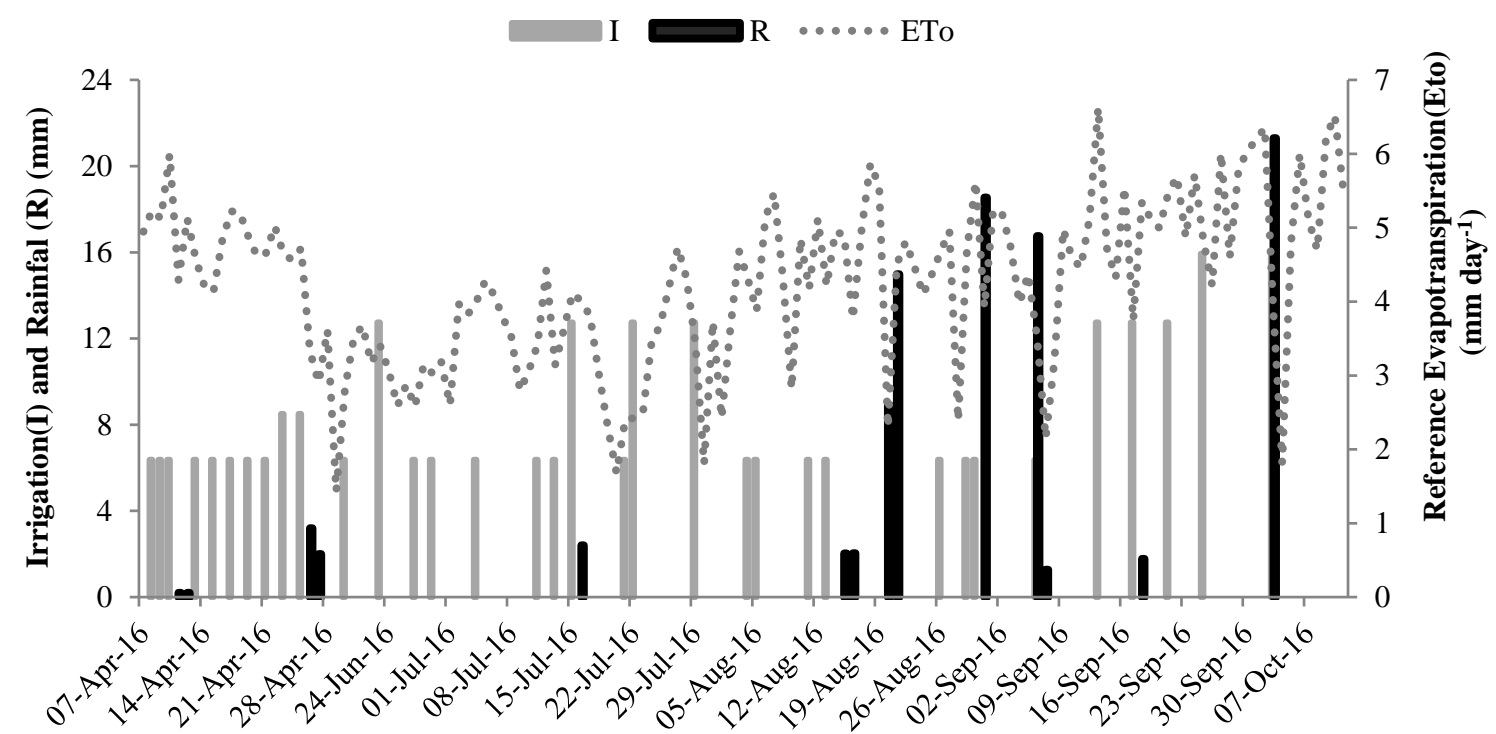

Figure 2. Irrigation (mm), Rainfall (mm) and reference evapotranspiration (ETo) during the data period, Piracicaba/SP, 2016.

Table 1. Correlation test (r) of the variables (AT versus L) per crop cycle.

\begin{tabular}{|c|c|c|c|c|c|c|c|}
\hline \multirow[b]{2}{*}{ Correlation } & \multicolumn{3}{|c|}{ Cycle/Plot } & \multirow[b]{2}{*}{ Correlation } & \multicolumn{3}{|c|}{ Cy cle/Plot } \\
\hline & $\mathrm{C} 1 \mathrm{P} 1$ & C2 P1 & C3 P1 & & $\mathrm{C} 1 \mathrm{P} 2$ & $\mathrm{C} 2 \mathrm{P} 2$ & C3 P2 \\
\hline LP1 x AT1 & $0,7796 * *$ & $-0,0065 \mathrm{~ns}$ & $0,3139 \mathrm{~ns}$ & LP2 $\times$ AT4 & $-0,5833 * *$ & $-0,0622 \mathrm{~ns}$ & $0,2989 \mathrm{~ns}$ \\
\hline LP1 1 AT 2 & $0,5185 * *$ & $-0,1685 \mathrm{~ns}$ & $-0,2456 \mathrm{~ns}$ & LP2 $\times$ AT5 & $0,2249 \mathrm{~ns}$ & $0,1209 \mathrm{~ns}$ & $0,1027 \mathrm{~ns}$ \\
\hline LP1 x AT3 & $0,7158 * *$ & $-0,1922 \mathrm{~ns}$ & $0,6183 * *$ & LP2 x AT6 & $0,7351 * *$ & $0,2488 \mathrm{~ns}$ & $0,6591 *$ \\
\hline AT $1 \times$ AT2 & $0,8823 * *$ & $0,6802 * *$ & $0,365 *$ & AT4 x AT5 & $0,6199 * *$ & $0,8612 * *$ & $0,8145 * *$ \\
\hline AT $1 \times$ AT3 & $0,9105 * *$ & $0,7950 * *$ & $0,3985 *$ & AT4 x AT6 & $-0,1749 \mathrm{~ns}$ & $0,8797 * *$ & $0,6344 *$ \\
\hline AT $2 \times$ AT 3 & $0,7951 * *$ & $0,8088 * *$ & $0,0187 \mathrm{~ns}$ & AT5 x AT6 & $0,5046 *$ & $0,9794 * *$ & $0,5187 \mathrm{~ns}$ \\
\hline
\end{tabular}

ns - not significant; * - significant at the $\alpha=5 \%$; ** - significant at the $\alpha=1 \%$

Table 2. Total Crop Evapotranspiration measured for weighting lysimeter (WT) and Diviner (D), analysis the errors (ME, MAE and RMSE), Willmontt's index and crop coefficient initial, middle and final estimated for WT and D in all cycles.

\begin{tabular}{|c|c|c|c|c|c|c|c|c|c|c|c|c|}
\hline Variables & \multicolumn{6}{|c|}{ Plot 1} & \multicolumn{6}{|c|}{ Plot 2} \\
\hline Cycle & \multicolumn{2}{|c|}{$C 1$} & \multicolumn{2}{|c|}{$C 2$} & \multicolumn{2}{|c|}{$C 3$} & \multicolumn{2}{|c|}{$C 1$} & \multicolumn{2}{|c|}{$C 2$} & \multicolumn{2}{|c|}{$C 3$} \\
\hline ETtotal (mm) WT & \multicolumn{2}{|c|}{83,93} & \multicolumn{2}{|c|}{136,57} & \multicolumn{2}{|c|}{127,35} & \multicolumn{2}{|c|}{76,69} & \multicolumn{2}{|c|}{107,55} & \multicolumn{2}{|c|}{113,35} \\
\hline ETtotal (mm) D & \multicolumn{2}{|c|}{109,05} & \multicolumn{2}{|c|}{183,54} & \multicolumn{2}{|c|}{189,6} & \multicolumn{2}{|c|}{165,64} & \multicolumn{2}{|c|}{183,59} & \multicolumn{2}{|c|}{167,22} \\
\hline ME* $(\mathrm{Kc})$ & \multicolumn{2}{|c|}{$-0,1717$} & \multicolumn{2}{|c|}{$-0,1147$} & \multicolumn{2}{|c|}{$-0,3365$} & \multicolumn{2}{|c|}{$-0,6149$} & \multicolumn{2}{|c|}{$-0,4014$} & \multicolumn{2}{|c|}{$-0,4492$} \\
\hline $\operatorname{MAE}^{*}(\mathrm{Kc})$ & \multicolumn{2}{|c|}{0,3126} & \multicolumn{2}{|c|}{0,5141} & \multicolumn{2}{|c|}{0,5979} & \multicolumn{2}{|c|}{0,6953} & \multicolumn{2}{|c|}{0,6031} & \multicolumn{2}{|c|}{0,5105} \\
\hline RMSE* $^{*}(\mathbf{K c})$ & \multicolumn{2}{|c|}{0,3850} & \multicolumn{2}{|c|}{0,5868} & \multicolumn{2}{|c|}{0,9465} & \multicolumn{2}{|c|}{0,9088} & \multicolumn{2}{|c|}{0,6782} & & \\
\hline d $(\mathbf{K c})$ & & & & & & & & & & & & \\
\hline Method & WT & $\mathrm{D}$ & WT & $\mathrm{D}$ & WT & $\mathrm{D}$ & WT & $\mathrm{D}$ & WT & $\mathrm{D}$ & WT & $\mathrm{D}$ \\
\hline$K \mathbf{c}_{\text {initial }}$ & 0,61 & 0,71 & 0,93 & 0,86 & 0,73 & 0,58 & 0,50 & 1,06 & 0,70 & 1,46 & 0,59 & 0,78 \\
\hline Kcmiddle & 0,65 & 0,84 & 0,73 & 1,19 & 0,60 & 0,62 & 0,52 & 1,77 & 0,80 & 0,64 & 0,77 & 1,42 \\
\hline$K c_{\text {final }}$ & 0,95 & 1,17 & 0,80 & 0,75 & 0,70 & 0,63 & 1,12 & 1,22 & 0,95 & 1,58 & 0,85 & 1,34 \\
\hline
\end{tabular}

*mean the Diviner and lysimeter. 